\title{
The Berlin Chansonnier and French Song in Florence, 1450-1490: A New Dating and Its Implications
}

\section{Citation}

Gallagher, Sean. 2007. The Berlin chansonnier and French song in Florence, 1450-1490: A new dating and its implications. Journal of Musicology 24(3): 339-364.

\section{Published Version}

doi:10.1525/jm.2007.24.3.339

\section{Permanent link}

http://nrs.harvard.edu/urn-3:HUL.InstRepos:3746877

\section{Terms of Use}

This article was downloaded from Harvard University's DASH repository, and is made available under the terms and conditions applicable to Other Posted Material, as set forth at http:// nrs.harvard.edu/urn-3:HUL.InstRepos:dash.current.terms-of-use\#LAA

\section{Share Your Story}

The Harvard community has made this article openly available. Please share how this access benefits you. Submit a story.

Accessibility 


\section{The Berlin Chansonnier and French Song in Florence, 1450-1490: A New Dating and Its Implications}

SEAN GALLAGHER

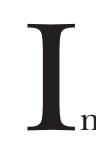

n August 1469 Marco Parenti, a well-to-do Florentine silk merchant, wrote a letter to Filippo Strozzi regarding the marriage prospects of Filippo's younger brother Lorenzo. Parenti was not a disinterested party in the matter: He was himself related by marriage to the Strozzi, a family of much greater prominence than the $\mathrm{Pa}$ renti, and thus his own social standing depended at least partly on maintaining the Strozzi's reputation through honorable marriage alliances. In the letter Parenti expresses his concern that Lorenzo may be unable to find a suitable bride. The problem, he says, is a lack of appropriate young women. To underscore this point he proceeds to catalogue the eligible daughters of various Florentine families, remarking on how each is lacking in one or more of the requisite qualities. One young woman has beauty, he says, but comes from a family without political standing in the city. Another comes with a highly respected name and a sizeable dowry, but she is not pretty. Yet another is trying to pass herself off as very young, but (as he cattily observes) "it is questionable whether she will succeed or not." Candid, gossipy, and frequently harsh in its criticism of his fellow citizens, Parenti's letter is valuable to historians of

\footnotetext{
A shorter version of this study was presented at the 72 nd Annual Meeting of the American Musicological Society (Los Angeles, November 20o6). I am grateful to Jane Alden, Giovanni Ciappelli, Anthony Molho, Keith Polk, Joshua Rifkin, and Marica Tacconi for helpful discussions of various issues addressed in this study.
}

The Journal of Musicology, Vol. 24, Issue 3, pp. 339-364, ISSN 0277-9269, electronic ISSN $1533-8347$. (C) 2007 by the Regents of the University of California. All rights reserved. Please direct all requests for permission to photocopy or reproduce article content through the University of California Press's Rights and Permissions website, http://www.ucpressjournals.com/reprintInfo.asp. DOI: 10.1525/ jm.2007.24.3.339. 
THE JOURNAL OF MUSICOLOGY

late medieval Florence, who cite it as evidence of the calculations prominent families invariably made in assessing the highly competitive marriage market. ${ }^{1}$

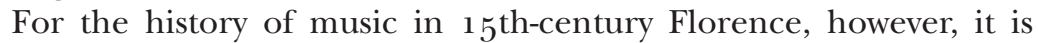
Parenti's mention of a particular young woman near the end of this passage-almost as an afterthought- that turns out to be of special significance (the relevant section of the letter is given in translation in the Appendix). The last family Parenti mentions are the Castellani: "There is the second daughter of Francesco Castellani. His first daughter who is married is not pleasing in any way, and they say the second is worse" (Écci la seconda di messer Francesco Castellani, la prima ch'è maritata non piace a verun modo, e la seconda dicono che è peggio). This "second" daughter is none other than Margherita Castellani, the original owner of the Berlin Chansonnier (Berlin, Staatliche Museen der Stiftung Preussischer Kulturbesitz, Kupferstichkabinett, MS 78.C.28), one of the most important collections of songs from the second half of the $15^{\text {th }}$ cen-

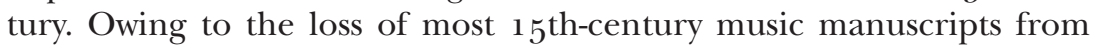
France and the Low Countries, chansonniers of Italian origin are crucial for our knowledge of song repertories and their dissemination. Florence appears to have been a particularly active center of collecting, judging from the survival of a group of nine chansonniers copied there between the 144 os and the early 1490 . The copying dates generally accepted for these manuscripts are based in most cases on the works they transmit and on the presence or absence of music by particular composers. ${ }^{2}$ In this context the importance of the Berlin Chansonnier has stemmed in part from its being the only Florentine collection from be-

1 Marco Parenti (1422-97) was brother-in-law to Filippo (1428-91) and Lorenzo Strozzi (1430-79), having married their sister Caterina (1431-81) in 1447. A significant obstacle to finding brides for both Filippo and Lorenzo was the fact that they were then living in Naples and had in fact spent most of their lives outside of Florence, the result of their father having been exiled by the Medici in 1434. On Parenti's role in the affairs of the Strozzi over many years, see Mark Phillips, The Memoir of Marco Parenti: A Life in Medici Florence (Princeton: Princeton Univ. Press, 1987). On Parenti's August 1469 letter to Filippo and the Florentine marriage market more generally, see Anthony Molho, Marriage Alliance in Late Medieval Florence (Cambridge: Harvard Univ. Press, 1994), 230-32; Judith Bryce, "Performing for Strangers: Women, Dance, and Music in Quattrocento Florence," Renaissance Ouarterly 54 (2001): 1090-92.

${ }^{2}$ The nine manuscripts are: Vatican City, Bibl. Apost. Vat., Urb. lat. 1411 (copied probably in the late 1440 ) ; the Berlin Chansonnier (on the date, see below); Florence, Bibl. Naz., MS Magl. xix.1 76 (ca. 1480); Florence, Bibl. Riccardiana, MS 2356 ("Second" Riccardiana Chansonnier; ca. 1480); Paris, Bibl. nat., fonds fr. 15123 ("Pixérécourt Chansonnier"; probably early to mid 1480s); Florence, Bibl. Naz., MS Banco Rari 229 (ca. 1492); Vatican City, Bibl. Apost. Vat., Cappella Giulia, XIII.27 (ca. 1492-94); Florence, Bibl. Naz., MS Magl. xix.178 (early 1490s); and Bologna, Civico Museo Bibliografico Musicale, MS Q17 (mid 1490s). On the dates of these manuscripts, see most conveniently the brief descriptions given in David Fallows, A Catalogue of Polyphonic Songs, I4I 5-I480 (Oxford: Oxford Univ. Press, 1999), 6-38, with further references there to the relevant literature. 
fore the 1490 for which there is external evidence for a more precise dating. The evidence in question is the year of Margherita Castellani's marriage, the date of which has seemed firmly established for more than 30 years and has figured prominently in discussions of $15^{\text {th- }}$ century song repertories and their sources. ${ }^{3}$ As we shall see, however, Marco Parenti's 1469 letter offers a first indication that the accepted date cannot be correct.

We can begin with a brief review of what is currently known about the Berlin Chansonnier. Figure 1 shows the first song in the collection with its decorated initial (depicting Tubalcain) and with heraldic arms in the lower margin. In 1973 Peter Reidemeister identified these as the arms of two prominent Florentine families, the Niccolini and Castellani, here impaled in a single shield signifying a marriage uniting two families. 4 The only marriage between these particular families during the $15^{\text {th }}$ century was that of Margherita Castellani and Bernardino Niccolini. The arms are heraldically correct and stylistically of a piece with the border decorations and initials found elsewhere in the manuscript. 5

3 In addition to Peter Reidemeister's monograph on the manuscript (see following note), in which the currently accepted dating of the chansonnier was first proposed, other relevant studies include Allan W. Atlas, "La provenienza del manoscritto Berlin 78.C.28: Firenze o Napoli," Rivista Italiana di Musicologia 13 (1978): 10-29; Leeman L. Perkins and Howard Garey, eds., The Mellon Chansonnier, vol. 2, Commentary (New Haven: Yale Univ. Press, 1979), 4-6, 152, 280-82; David Fallows, "Polyphonic Song in the Florence of Lorenzo's Youth, ossia: The Provenance of the Manuscript Berlin 78.C.28: Naples or Florence?" and Flynn Warmington, "The Missing Link: The Scribe of the Berlin Chansonnier in Florence," both in La musica a Firenze al tempo di Lorenzo il Magnifico, ed. Piero Gargiulo (Florence: Leo S. Olschki, 1993), 47-61; 63-68. See also Helmut Boese, Die lateinischen Handschriften der Sammlung Hamilton zu Berlin (Wiesbaden: Harrassowitz, 1966), 215-16; and Census-Catalogue of Manuscript Sources of Polyphonic Music, I40o-I 55o, RMS 1 (Neuhausen-Stuttgart: American Institute of Musicology and Hänssler-Verlag, 1979, 1988), I: 59-6o, IV:272.

4 Peter Reidemeister, Die Chanson-Handschrift 78 C 28 des Berliner Kupferstichkabinetts (Munich: Emil Katzbichler, 1973), 16-18. By the mid 15th century the Niccolini were by far the stronger of the two families, both politically and financially. The Castellani had sided with the anti-Medici faction in 1433 , a decision that had disastrous consequences for the family's political standing after Cosimo de' Medici returned from exile the following year. On the political and social prominence of the Castellani prior to 1434, see Lauro Martines, The Social World of the Florentine Humanists, I390-1460 (Princeton: Princeton Univ. Press, 1963), 199-210; Giovanni Ciappelli, Una famiglia e le sue ricordanze: I Castellani di Firenze nel Tre-Quattrocento (Florence: Leo S. Olschki, 1995), 7-47, provides a more detailed account that extends to later in the century.

5 Reidemeister, Die Chanson-Handschrift, 12 , suggests that stylistic features of the decoration on fol. $2 \mathrm{v}$ of the manuscript recall the work of the Florentine miniaturists Gherardo and Monte di Giovanni, whose workshop has been associated with the decoration of two other Florentine song collections of this period, the Pixérécourt Chansonnier and Florence, MS Banco Rari 229; on the decoration of the latter two manuscripts see Howard Mayer Brown, ed., A Florentine Chansonnier from the Time of Lorenzo the Magnificent: Florence, Biblioteca Nazionale Centrale MS Banco Rari 229, MRM 7, Text Volume (Chicago: Univ. of Chicago Press, 1983), 9-15. Doubts have been raised, however, about Reidemeister's proposed identification of the illuminators of the Berlin manuscript; see Fallows,

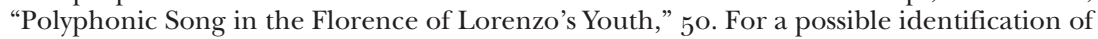
the Berlin miniaturist, see below, $35^{1}$. 
THE JOURNAL OF MUSICOLOGY

There is no evidence of repainting or overpainting of any kind, and so we can be certain these are the original arms. Reidemeister suggested that the chansonnier was intended as a wedding gift, though he had no direct evidence of when Margherita and Bernardino's marriage took place. Basing his remarks on the work of the 19th-century genealogist Luigi Passerini, Reidemeister stated that Margherita's own parents had married in 1447. In turn he estimated that Margherita, their second child, was born around 1450. Again following Passerini, he claimed that the first of Margherita and Bernardino's four sons was born in 1467 , which led him to propose that they married in $146_{5}$ or 1466 , when Margherita would have been about 15 years old. If the chansonnier was a wedding gift, Reidemeister argued, then $1465 / 66$ should be seen not simply as a terminus post quem, but rather the terminus ad quem for the manuscript, and this is in fact how it has been treated in subsequent scholarship.

All 42 songs in the manuscript were copied by a single scribe in a notably elegant hand. In the early 1990s Flynn Warmington identified this scribe in another music manuscript of securely Florentine origin (Florence, Opera del Duomo, MS 21 ), a partbook for two-voice processional music used for Holy Week at the Duomo. ${ }^{6}$ Her observations concerning the impaled arms are useful with regard to the dating of the Berlin Chansonnier. She notes that since all such arms represent particular individuals, not simply alliances between families, these arms are specifically Margherita's following her marriage to Niccolini. Their presence in the chansonnier, and the absence of any independent appearance of the Niccolini family arms, tells us that the book actually belonged to her. Whereas Reidemeister often referred to it as the "Niccolini Chansonnier," it would be more accurate (following Warmington) to call it "Margherita Castellani’s Songbook."7

6 Flynn Warmington, "The Missing Link," 63-68. Giulio Cattin, in his study of the Duomo manuscript, suggested Scribe A's work dates from ca. $1480-1500$, a good deal later than the accepted dating of the Berlin Chansonnier; see his "Un processionale fiorentino per la settimana santa: studio liturgico-musicale sul ms. 21 dell'Opera di S. Maria del Fiore," Quadrivium 15 (1974): 73. Based on similarities of scribal detail in the two sources, however, Warmington believed the two books to have been copied within a relatively short time span and suggested the Duomo source could be from as early as the late 1460 .

7 Warmington, "The Missing Link," $65-66$. To be fair, Reidemeister's decision to call it the "Niccolini Chansonnier" was not unjustified, since the book appears at some later point to have belonged to a member of the Niccolini family. As there are no signs of subsequent ownership (the most common of these being the replacement of the arms), it is even possible it remained in the Niccolini family until it was purchased (probably in the early 1780 s) by the writer and collector William Beckford (176o-1844); see Reidemeister, Die Chanson-Handschrift, 23-24. 
Figure 1. Berlin, Staatliche Museen der Stiftung Preussischer Kulturbesitz, Kupferstichkabinett, MS 78.C.28, fol. 2v

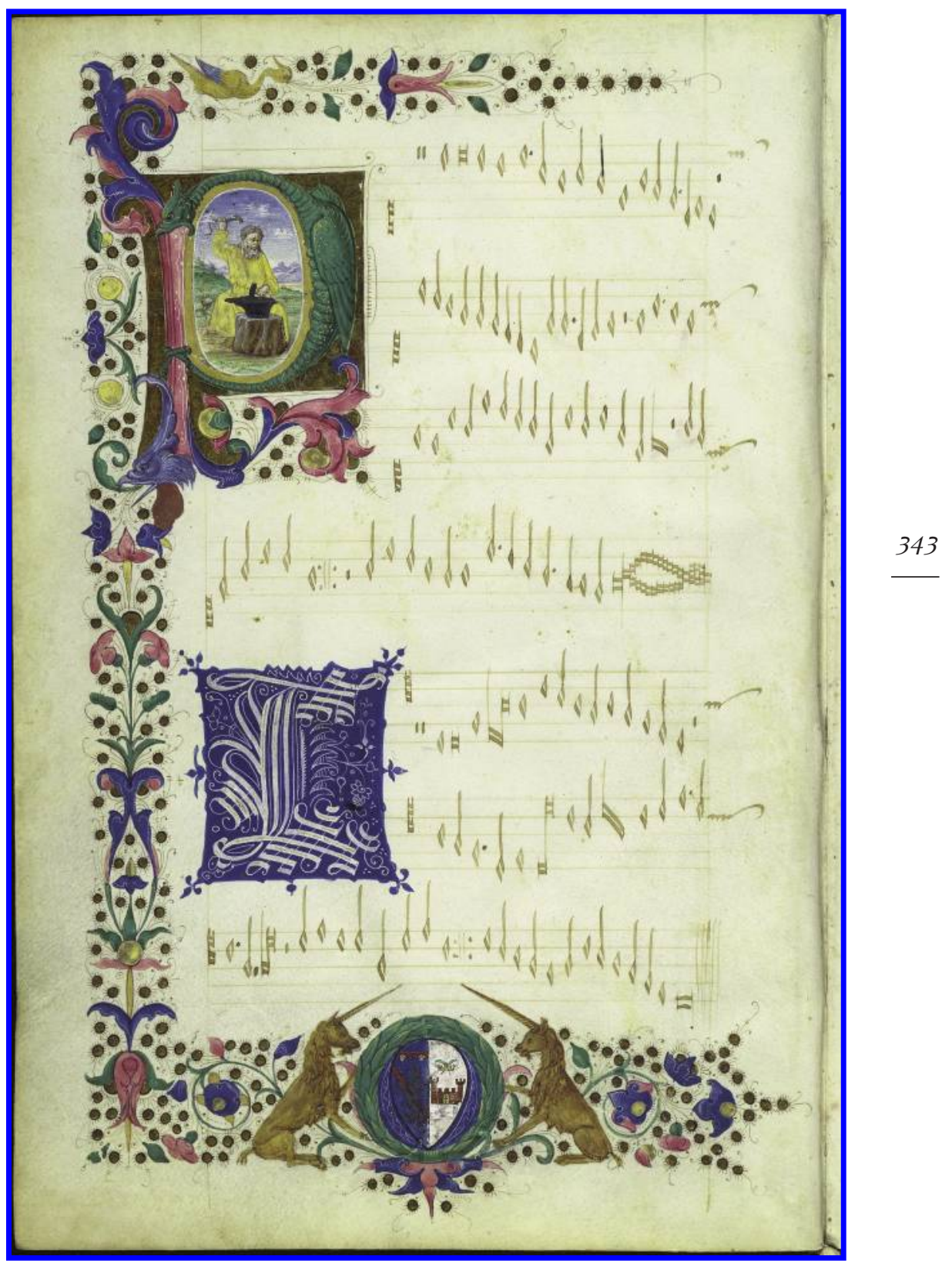


THE JOURNAL OF MUSICOLOGY

Since the arms merely reflected Margherita's marital status, Warmington observes that we should be cautious in assuming the book was necessarily connected to the wedding. The manuscript could have been made at any point during her marriage to Niccolini (who died in 1489; it is not known when Margherita herself died, but she was alive still in 1494). ${ }^{8}$ Warmington nonetheless accepted the date of $1465 / 66$, at least as a terminus post quem, suggesting only that we should not rule out the possibility that it was copied later in the $1460 \mathrm{os}$. She noted that the nature of the repertory was the main reason for dating the manuscript "before ca. 1470 (or perhaps a few years later)," in particular the fact that it contains no music by Antoine Busnoys, whose works began appearing elsewhere in Italy during the 1470 . She was careful to note, though, that this ca. 1470 borderline is provisional, "for it depends on general ideas about the Florentine chanson repertory in the 1470 , a period to which no surviving local sources can be securely assigned."9 I will return to the question of Busnoys's music in Florence.

For a number of years now the Berlin manuscript has been our only Florentine source from the 1460 s. In tracking the dissemination of French chansons by means of the relative dating of manuscripts and the works they contain, it has been immensely helpful to have a collection of Italian origin from before the 149 os that could be dated fairly precisely and thus serve as a stable point of reference. New evidence, however, calls for a series of small but crucial adjustments to the theories proposed by Reidermeister that together force a reassessment of the dating of the Berlin Chansonnier. This reassessment affects in turn its relation to several other manuscripts, both from Florence and elsewhere in Italy, and provides new insight into the repertory of songs that circulated in Florence in the $14605,70 s$, and even early 80 s.

There is first of all the passage in Marco Parenti's letter of August 1469 , which states that while Francesco Castellani's eldest daughter was already married, his second daughter was not. If true, Parenti's statement would tell us that Margherita Castellani's wedding took place at least three or four years later than Reidemeister claimed. The letter as a whole reveals that Parenti was well informed about the social elite of Florence and their daughters of marrying age, and various documents housed in the Archivio di Stato in Florence confirm the details of his reference to the Castellani. Among these is the libro di ricordi of Francesco Castellani, Margherita's father, who like many Florentines kept such a book with entries on matters of all sorts concerning him

\footnotetext{
8 Margherita's father died in 1494; mention of her in his will (drawn up the same year) confirms she was still alive then; see Ciappelli, Una famiglia, 94-95.

9 Warmington, "The Missing Link," 66.
} 
and his family, especially anything having to do with their finances. One relevant entry in his Ricordanze concerns the large dowry of 1700 florins he received upon marrying Lena Alamanni, Margherita's mother. He notes that he collected the money on 18 February 1449 (all dates given here are new style). Giovanni Ciappelli, who recently edited Castellani's Ricordanze, has located the notarial document confirming that Francesco and Lena had in fact gotten married about two weeks earlier, on February $5^{\text {th. }}{ }^{10}$ Thus Margherita's parents married about two years later than Reidemeister believed. Other archival documents reveal that the couple had three children who survived to adulthood, all of them daughters: Maria, the eldest, then Margherita (thus confirming that she was the second daughter mentioned by Parenti), and finally Ginevra. ${ }^{11}$

It is in the records of the Monte delle Doti, or Dowry Fund, that we find detailed information on all three daughters and their marriages. These records are especially useful documents, and a bit of background on the Monte delle Doti will help clarify why this is so. ${ }^{12}$ The Florentine government first launched the Dowry Fund in the 1420 s as a way of combating two socio-economic problems: 1) the city's rapidly rising public debt, and 2) the often crippling financial burden families faced when their daughters married and they had to provide adequate cash dowries for them. The basic principle of the Fund was simple: a girl, usually while still quite young, could be enrolled in the Monte by her father or guardian, who would make a cash deposit-say of 1 oo florins-with the officials of the public debt (the Monte comune). The deposit was for a predetermined length of time (normally between $7^{1 / 2}$ and 15 years) and at a set rate of interest. Years later, once the girl had consummated her marriage, her husband could then claim the dowry from the Monte officials. Though the Fund had some unanticipated consequences for the city's finances, the scheme was largely successful in helping families provide for their daughters' dowries without having to lay hands on large amounts of cash at short notice.

The account books of the Monte were legally binding documents involving sizeable sums of money, and the officials responsible for them were understandably meticulous in their recording of information. Thus when an account was set up for a girl, the following details were invariably recorded: her full name and exact date of birth; the names of both parents and both grandfathers; the amount deposited and rate of

1o Giovanni Ciappelli, Francesco di Matteo Castellani, Ricordanze, vol. 1 (Florence: Leo S. Olschki, 1992), 16-17, 141 .

11 Ciappelli, Ricordanze, vol. 1, 19-21.

12 What follows here on the Monte delle Doti is based on the thorough description of its origins and workings in Molho, Marriage Alliance, 27-79. 
THE JOURNAL OF MUSICOLOGY

interest, the term of the account, the amount eventually to be paid out, and the name of the official registering all of this information. Furthermore, when it came time to pay out the dowry to the husband, the details of this transaction were recorded directly beneath the initial account entry. So it is that one can determine that Francesco and Lena Castellani's eldest daughter, Maria, was born 22 March 1450, when they had been married for just over a year. A dowry account was set up for her approximately a year and a half later, on 12 August 1451, for a term of 15 years. As it happened, she had not yet married by 1466 , when the account matured. But subsequent entries in her account confirm that at age 19 she married Giovanni Cavalcanti, who collected his dowry on 20 September $1469 .{ }^{13}$ They obviously had only recently gotten married, which confirms Marco Parenti's description of her as married in his August 1469 letter and perhaps explains why he thought to mention her at all: The wedding must have taken place just a short while earlier and was still fresh in his memory.

The records of the Dowry Fund also provide biographical details about Margherita Castellani. Her account tells us that she was born on 21 December 1453, not $145^{0 .}{ }^{14}$ In this case Reidemeister's estimate was off by just three years, but even without the evidence of Parenti's letter that Margherita was still unmarried in 1469 , her birth date near the very end of 1453 would rule out the possibility that she married in ${ }_{14} 6_{5}$ or 1466 , since the minimum age at which a girl could wed was $13 .{ }^{15}$ She would not then have given birth to her first son (reportedly named Placido) in 1467 -the basis for Reidemeister's claim that the wedding took place in $146_{5}$ or 1466 . The report concerning their son, which apparently derives from the genealogist Passerini, was likely the result of a misread name. There is no evidence for anyone named "Placido" in either the Niccolini or Castellani families. But in 1467 or 1468 Bernardino Niccolini, prior to marrying Margherita and while still living in his father Otto's house, fathered illegitimate twin sons, named Tacito and Romolo. Both Bernardino and the twins are named among the members of Otto Niccolini's household in a catasto account of $1470 .{ }^{16}$ Probably Passerini simply misread "Tacito" in one the docu-

13 Maria's full dowry account is divided between two sets of Monte records (Florence, Archivio di Stato, Monte comune, 3735 , fol. $15^{\mathrm{v}}$ and 3737 , fol. $113 \mathrm{r}$ ); see also Ciappelli, Ricordanze, vol. 1, 29.

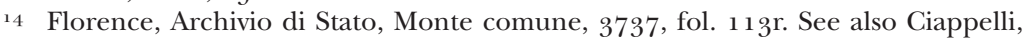
Ricordanze, vol. 1, 21.

15 Anthony Molho (Marriage Alliance, 161 and 307) has demonstrated that it was rare in the late 15 th century for Florentine girls to marry before the age of about 15 , and for those from wealthier families the average age appears to have been closer to 18 .

16 Bernardino was the second son of Otto di Lapo Niccolini $(1410-70)$, the most important member of the family in the $15^{\text {th }}$ century. The twins are listed in the catasto 
ments he consulted. At all events this Tacito was not the child of Margherita and Bernardino, and so his birth date cannot be used as a terminus ante quem for their marriage. On the contrary, the reference to Bernardino in his father's catasto account tells us he had not yet married as of 1470 .

The volume in which Margherita's Dowry account is preserved has suffered some water damage (possibly during the infamous flood of 1966), and this has made it difficult to read certain words. ${ }^{17}$ Fortunately all the relevant details are still legible.

ASF, Monte comune, 3737, fol. $113^{\mathrm{r}}$ :

Margherita el primo e Franciescha el sechondo figliuola di messer Francesco di messer Matteo [C] hastellani e di madonna Lena sua donna e figliuola di Francesco di Piero Alamanni, nata a dì 21 di dicembre 1453 , de' avere per dì 19 di marzo 1468 (1469 n.s.) fiorini dccclviiij soldi viiij per f.164 s.16 danari 9 di contanti per valuta di f. 1063 s. 1 o d. ij a $15^{1 / 2}$ per cento che Cristofano di Guariente questo a dì 18 di marzo 1457 ( $145^{8}$ n.s.) al quaderno [a] c. 9 e per anni xj.

f. dccclviiij s. viiij

A ne auto a dì xv d'ottobre $1472 \mathrm{f}$. sessantadue s. otto ... per lei a Bernardino di messer Otto Nicolini suo marito per ... da Franc[esco] [Ca]rnesechi camarlingo al Monte.

f. 62 s. 8

A ne auto a dì 30 di giugno 1473 f.664 larghi per lei a Bernardino sopradetto suo marito, ebe chontanti da Bartolomeo Telli kamarlingo al Monte, valutaf. 796 s. 16

$$
\text { [f.] } 859 \text { [s.] } 4
$$

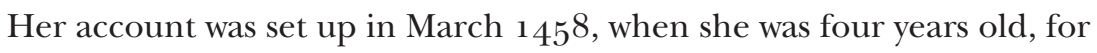
a term of 11 years. As with her elder sister, Margherita's account matured before she married, but the two subsequent entries in her account record two separate payments to Bernardino di Otto Niccolini, who in both instances is described as Margherita's "husband" (suo marito). The first payment, on 15 October 1472 , is very small, a mere 62 florins, constituting about $7 \%$ of the total dowry. Bernardino collected the remaining 796 florins eight months later, on 30 June 1473 .

account as being two years old (thus born in 1467 or 1468). See Ginevra Niccolini di Camugliano, The Chronicles of a Florentine Family, I 200-I 470 (London: Jonathan Cape, 1933), 1 79-326 (on Otto's political career); the catasto document is discussed at 182-84; on Otto's possible involvement in acquiring at least some of the songs found in the Berlin Chansonnier, see below, 361 .

${ }^{17}$ For the location of her account, see note 14 above. I am grateful to Giovanni Ciappelli for help in deciphering parts of Margherita's account. 
THE JOURNAL OF MUSICOLOGY

It is not entirely clear to me, nor to the specialists I have consulted, why there were two payments separated by a period of several months. As we have seen in the case of Margherita's father, who collected his entire dowry within two weeks of marrying, husbands tended to collect their dowries as soon as possible after consummation. But it would seem such dual payments were not uncommon; other accounts with similar payments appear on the same page as Margherita's. ${ }^{18}$ Whatever the explanation, the division of the dowry into separate payments does not affect the significance of this document for the dating of the Berlin Chansonnier. In order for Bernardino to have claimed any part of the dowry, the marriage would had to have been consummated, and so the evidence indicates that they married sometime before he received the first payment on 15 October 1472 , probably a matter of weeks or days, rather than months. If we believe the songbook was intended as a wedding present, the earliest terminus post quem for the manuscript and its decoration would be sometime earlier in 1472 .

But was this book in fact a wedding gift? Or, as Warmington suggests, could it have been copied at some later point in their marriage? Was this simply a collection of songs Margherita had made for herself? The strongest evidence for the manuscript having been prepared in connection with the wedding would seem to be not the impaled arms of the two families, but rather the two unicorns supporting these arms (see Figure 1). The unicorns are an unusual feature. Countless $15^{\text {th- }}$ century Italian manuscripts contain arms supported in this way, but the figures depicted are almost always putti or angels, a practice that holds true even in manuscripts explicitly linked with weddings or betrothals. ${ }^{19}$ Depictions of animals of any sort are rare, and I have thus far found no other Italian examples of arms flanked by unicorns. But given the broad association of unicorns with the virtues of chastity and faithfulness in marriage, it is not surprising to find them figuring in other wedding-related contexts, such as the painted panels made for bridal

${ }_{18}$ It is possible the first small payment to Bernardino involved the taxes (gabelle) husbands were required to pay on the money they received from dowries. The rates of these taxes fluctuated over the decades, but it so happens that in the early 1470 os these were set at $7 \%$ of the total, approximately the amount Bernardino received in October 1472. It is not clear in all cases how these taxes were collected. Perhaps Bernardino was to pay this small amount in turn to another set of civic officials. On the gabelle, see Molho, Marriage Alliance, $55^{-5} 5^{8 .}$

${ }_{19}$ For a nuptial hymn decorated with the arms of the two families held by an angel, see Annarosa Garzelli, Miniatura fiorentina del rinascimento, I440-1525: Un primo censimento, 2 vols. (Scandicci, Florence: Giunta Regionale Toscana, La Nuova Italia, 1985), vol. 2, ill. 856 . Similarly, an angel holds the ducal arms of the Sforza and Este families on a 1477 contract that spells out the terms of the betrothal of Anna Sforza and Alfonso d'Este (Archivio di Stato di Modena, Casa e Stato, serie generale, Cass. 25, no. 76). 
cassoni of a type especially popular in 15 th-century Tuscany. ${ }^{20}$ Still, their use in the Berlin Chansonnier is sufficiently unusual as to suggest the possibility of some sort of personal emblem, one which Margherita could just as well have chosen to decorate a songbook commissioned at some later point in her marriage (faithfulness being no less valued after the wedding than before).

Another distinctive feature of the book points to something having gone awry during the final stages of its production. Many chansonniers, especially ones copied in Italy after about $145^{\circ}$, contain incomplete or hopelessly garbled texts, often providing nothing more than incipits. Whether a result of indifference or incompetence is not always clear, but there is rarely any reason to believe the texts look as they do because the manuscript was left unfinished (if anything it is the painted intials and other types of decoration that are left incomplete). But the Berlin Chansonnier was without question left unfinished, and in a way that is unique among all surviving song collections. The scribe completed the music and provided catch letters at the beginning of voice parts for the illuminator, who in turn painted handsomely decorated initials throughout. The oddity here is that apart from these catch letters, the scribe copied no texts, not even incipits. ${ }^{21}$ However, he must have worked from an exemplar (or exemplars) that at the very least contained incipits of the texts, since for songs for which concordances exist the initials given in the discantus parts are the correct ones. ${ }^{22}$ Why

${ }_{20}$ An example is Francesco di Giorgio Martini's panel painting Il Trionfo della castità (now in the Getty Museum), which was made for a cassone in connection with a wedding in 1464 between members of the Gabrielli and Luti families. The painting depicts Chastity in a carriage drawn by a pair of unicorns.

${ }_{21}$ One song in the manuscript, Le serviteur hault guerdonné (no. 2, fols. $4{ }^{\mathrm{v}-} 5^{\mathrm{r}}$ ), is provided with one stanza of text underlaid to the cantus, and incipits for the other two voices, but these were entered by a different though not necessarily later hand. This second scribe's hand resembles in many ways that of the main scribe of the "Second" Riccardiana Chansonnier (Florence, Bibl. Riccardiana, MS 2356; copied ca. 1480). The two hands are not identical, but the overall character of the script would be consistent with this added text having been written in Florence in roughly the same period as the copying of the chansonnier.

${ }_{22}$ The one exception is Viva viva rey Ferrando (fols. $37 \mathrm{v}-39 \mathrm{r}$ ), a four-voice canción (without vuelta) honoring Ferrante I of Aragon, King of Naples, the only other source for which is Montecassino, Biblioteca dell'Abbazia, MS 871, a manuscript from the area around Naples copied probably in the 1470s. The copy in the Berlin manuscript has the initials "S" and "D." Presumably the Berlin scribe's exemplar carried a different (possibly French) text in place of the Castilian original. Editions of the work are in Reidemeister, Die Chanson-Handschrift, no. 34 (with facs. of both versions); Isabel Pope and Masakata Kanazawa, eds., The Musical Manuscript Montecassino 871: A Neapolitan Repertory of Sacred and Secular Music of the Late Fifteenth Century (Oxford: Oxford Univ. Press, 1978), 442-48 (with facs. of the Montecassino version, plate 7); Allan W. Atlas, Music at the Aragonese Court of Naples (Cambridge: Cambridge Univ. Press, 1985), 163-66. That the Berlin version was intended to be a contrafact of the Castilian-texted original in Montecassino 871 
THE JOURNAL OF MUSICOLOGY

did the scribe not copy the texts or their incipits before sending the collection on to the illuminator, as was normally done? One possible explanation is that the Berlin scribe's text hand may not have been sufficiently elegant for such a book, and so a second scribe with a better hand was to have entered these. ${ }^{23}$ Support for this possibility comes from the processional partbook copied by the Berlin scribe for the Duomo (see n6 above). The texts he copied there reveal a hand that is competent but nothing more. ${ }^{24}$ If he was capable of nothing better, there might well have been a plan to have a second scribe enter the texts. But even in this scenario it remains a mystery why this second scribe did not copy the texts before sending them on to the illuminator.

The manuscript provides one further intriguing clue in all this. What was surely intended to be the last piece in the collection, the songmotet $O$ pulcherrima mulierum (fols. $49^{\mathrm{v}-5}$ ov), is incomplete: The work was to occupy two openings in the manuscript, but the scribe broke off after copying just the discantus of the secunda pars, omitting the tenor and contratenor that should have appeared on fol. $5^{1 r^{25}}$ This unfinished last piece suggests something interrupted the final stages of copying. Nevertheless a decision was made to go ahead and pass it on to the illuminator as it was. Whether it was the intention that texts be eventually added we cannot know, but one can infer from this decision that the manuscript's status as a visual object was considered at least as important as its textual contents.

Both the use of fine parchment and the attractive musical notation indicate a desire to emphasize the visual component of the book, as does the artistic quality of the painted initial that opens the collection

has been demonstrated by David Fallows; see his "A Glimpse of the Lost Years: Spanish Polyphonic Song, 1450-1470," in Josephine Wright with Samuel A. Floyd, Jr., eds., New Perspectives on Music: Essays in Honor of Eileen Southern (Warren, MI.: Harmonie Park Press, 1992), 32-33; repr. in David Fallows, Songs and Musicians in the Fifteenth Century (Aldershot: Ashgate, 1996). Fallows's observations effectively refute Reidemeister's claim (Die Chanson-Handschrift, 103-5; echoed by Pope and Kanazawa, 639-40, and Atlas, 148-50) that the text Viva viva rey Ferrando was actually the contrafact. On the significance of the Neapolitan origins of this song, see below, 362 .

${ }_{23}$ The idea of there having been a separate text-scribe for the chansonnier has been proposed by Reidemeister (Die Chanson-Handschrift, 14).

${ }_{24}$ The catch letters in the Berlin manuscript match the text hand in Florence, Opera del Duomo, MS 21.

${ }_{25}$ This anonymous setting of $O$ pulcherrima mulierum survives in a number of sources, among them two Florentine songbooks dating from ca. 148 o or perhaps slightly later (the "Second" Riccardiana and Pixérécourt chansonniers; on the copying of the latter, see below); for a complete list of these sources see Fallows, Catalogue of Polyphonic Song, 591 (the absence of the tenor and contratenor parts in the Berlin chansonnier is there mistakenly attributed to the relevant page having been lost). An edition of the work, with a tentative attribution to John Plummer, is in Reinhard Strohm, Music in Late Medieval Bruges, rev. ed. (Oxford: Clarendon Press, 1990), 224-26. 
(see Fig. 1). This depiction of Tubalcain is almost certainly the work of one of the many accomplished miniaturists then active in Florence. ${ }^{26}$ The recent identification of the scribe of the Berlin manuscript with the copyist of a collection of processional music for the Duomo strengthens the possibility that the decoration of the chansonnier was also done by one of the several artists who in this period worked on a group of elaborate liturgical manuscripts for the Duomo. ${ }^{27}$ The miniatures by most of these artists differ stylistically from the Berlin Tubalcain. But painted initials attributed to two of these miniatori, Francesco d'Antonio del Cherico (active from the early $145 \mathrm{os,} \mathrm{died} \mathrm{1484)} \mathrm{and}$ Benedetto di Silvestro (active between 1445 and 1473), are very similar to the Berlin painting in their handling of facial details and background landscapes. ${ }^{28}$ Benedetto might be an especially promising candidate: He was a priest and cappellano at the Duomo from the mid 144 os until at least 1460 , and from 1461 a canon in nearby Fiesole. He was still active as a miniaturist in 1473 . More importantly in the context of the Berlin Chansonnier, there is documentation of Benedetto having worked on at least one occasion for Francesco Castellani, Margherita's father: In $145^{8}$ Castellani paid him for having painted miniatures in a Bible. ${ }^{29}$ If the commissioning of the chansonnier originated with the Castellani (either Francesco or Margherita), then the family might well have turned to an artist they already knew.

Whatever the case-whether the manuscript was made for the wedding or at some later point-the archival evidence concerning Margherita's marriage reveals that the chansonnier dates from a number of years later than has been believed. What has long been thought to be our only Florentine source from the 1460 s must actually date from sometime in the following decade.

${ }_{26}$ Reidemeister saw similarities with the work of Gherardo and Monte di Giovanni, though this is difficult to support on stylistic grounds, and at least one authority on Quattrocento manuscripts, Albinia de la Mare, has raised doubts about the attribution, as reported in Fallows, "Polyphonic Song in the Florence of Lorenzo's Youth," 5 o.

${ }_{27}$ On these manuscripts, three graduals and an antiphonary produced between 1445 and $1477 / 78$, and the artists known to have worked on them, see Marica S. Tacconi, Cathedral and Civic Ritual in Late Medieval and Renaissance Florence (Cambridge: Cambridge Univ. Press, 2005), 144-70 and Appendix B.

28 On Francesco del Cherico, see Mirella Levi D'Ancona, Miniatura e Miniatori a Firenze dal XIV al XVI secolo (Florence: Leo S. Olschki, 1962), 108-16. Particularly striking similarities with the Berlin Tubalcain can be seen in the hair and facial details of a miniature attributed to Francesco in the antiphonary Florence, Bibl. Medicea Laurenziana, Edili 148, fol. 66r; color facs. in Tacconi, Cathedral and Civic Ritual, 326 (Plate 13). Boese (Die lateinischen Handschriften, 216) described the painting of Tubalcain and the arms in the Berlin manuscript as "stilistisch nach Florenz (in den Kreis des Francesco d'Antonio del Cherico) gehörend." On Benedetto di Silvestro, see Levi d'Ancona, Miniatura e Miniatori, 65-69, 293-94 (Tavola 9); Tacconi, Cathedral and Civic Ritual, 153 n35, 262.

29 Ciappelli, Una famiglia, $169 n_{42}$. 
THE JOURNAL OF MUSICOLOGY

The implications of this later dating are manifold. In order to address these we must leave archival documents and turn to the contents of the Berlin Chansonnier and its concordant sources. Perhaps the first observation one should make here is that given the music it contains, one would expect any re-dating of the Berlin manuscript to have moved it several years earlier, not later. That is to say, many of these songs, based on the dates of their earliest sources, were far from new when the manuscript was copied. Indeed, much of the music must have been composed between the mid 144 os and the early to mid 145 os. Of the 33 songs in Berlin for which we have concordances, at least 26 (approximately $80 \%$ ) appear in sources copied by ca. 1460 , many of them in manuscripts finished already by the mid 145 os. Table 1 provides a list of the works in the Berlin Chansonnier, along with its concordant sources in roughly chronological order (from left to right). These include 13 songs that were copied into the manuscripts Trent 93 and 9o, which Peter Wright has shown were finished by ca.1455. ${ }^{\circ}$ There are also two songs that appear already in an older Florentine manuscript, Vatican, Urb. lat. $14^{11}$ (written in black notation and dating most likely from the 1440s), as well as six songs found in the Porto manuscript, copied probably in Ferrara in the mid to late $145^{\mathrm{os}} .^{3^{1}}$ The source with the largest number of concordances with Berlin is Escorial B, a large collection copied in stages by several scribes, the main corpus of which is of northern Italian, possibly Milanese, origin..$^{2}$ Berlin and Escorial B have 18 works in common, 16 of which were copied in early layers of Escorial that most probably date from the mid to late $145^{\mathrm{os}}$, based on watermark evidence and the absence of songs with low contra-

3o Peter Wright, "Johannes Wiser's Paper and the Copying of His Manuscripts," in Peter Wright, ed., I codici musicali trentini: nuove scoperte e nuovi orientamenti della ricerca (Trent: Provincia autonoma di Trento, 1996), $3^{1-53}$.

${ }^{31}$ James Haar, "The Vatican Manuscript Urb. lat. 1411: An Undervalued Source?" in Marco Gozzi, ed., Manoscritti di polifonia nel quattrocento Europeo (Trent: Provincia autonoma di Trento, 2004), 65-92. The dating of Porto, Bibl. Pública Municipal, MS 714 has been debated for years, notably in various publications of David Fallows and Lewis Lockwood. Though the matter calls for further research on Ferrarese manuscripts in the time of Borso d'Este, the strongest evidence presently available is that presented by Lockwood, which points to a date between ca. 1454 and 1460; see his Music in Renaissance Ferrara, I4OO-I5O5 (Cambridge: Harvard Univ. Press, 1984), 109-18. Fallows's judgment that "in terms of its repertory [Porto] belongs firmly in the 1460 " (first published in 1981 and later reiterated in his review of Lockwood's book on Ferrara; Early Music History 6 [1986]: 293), now seems untenable in light of more recent research on the dating of manuscripts with which Porto shares numerous works (e.g. Escorial B, Trent 9o). Fallows's most recent published statement on the matter (Catalogue of Polyphonic Songs, $3^{8}$ ) is that the manuscript was "probably copied at Ferrara in the early 1460 s. IV.a.24.

$3^{2}$ Real Monasterio de San Lorenzo del Escorial, Biblioteca y Archivo de Música, MS 
tenors.33 Similarly, the Berlin manuscript has only two works with low contratenors-Robert Morton's rondeau N'aray je jamais and the anonymous unicum on fols. $6 \mathrm{v}-7 \mathrm{r}$.

In chansonniers of this period it is not unusual to find some older songs mixed in among more recent repertory. But a collection like the Berlin Chansonnier, in which the lion's share of the music was some 15 to 25 years old at the time of copying, is surprising, to say the least. For the sake of comparison we might consider the Cordiforme Chansonnier, a beautifully decorated collection of songs almost identical in size to Berlin (43 songs to Berlin's 42) and with a comparable number of unica ( 13 in Cordiforme, nine in Berlin). The two manuscripts even have eight songs in common. But in terms of older repertory the difference between the two chansonniers is striking: In Cordiforme, older works make up only about $30 \%$ of the music, far less than the $80 \%$ we find in Berlin. This comparison is especially revealing in light of the new dating of the Berlin manuscript. Cordiforme was copied in Savoy before 1477 , most probably between 1470 and 1476 , which is to say that it is not only comparable in size to the Berlin Chansonnier but was also copied in the very same years.34 The revised dating, in eliminating the chronological distance between the two manuscripts, places in relief their repertorial differences.

How are we to account now for these differences? Geography provides one possible explanation. Knowing that the Berlin Chansonnier was copied in Florence in the 1470s, we now have firsthand information concerning the circulation of the more recent repertory of French songs in Florence during these years-works by composers such as Busnoys, Ockeghem, Caron, and others of their generation. As Warmington was careful to note, the long-standing idea that music by Busnoys and the others was known in Florence throughout the 1470 os has really been based on an assumption-one made in the absence of datable sources. With the Berlin Chansonnier as a witness we are now able to test this theory. A comparison of the contents of the Berlin volume with those of other Italian chansonniers copied in the 1470 os and 80 os is revealing: It seems clearly to be the case that the songs of Busnoys (the most prolific composer of chansons in this period) began to circulate

33 Fallows, Catalogue of Polyphonic Songs, $15^{-16}$; to the relevant literature mentioned there should be added Dennis Slavin's important article "On the Origins of Escorial IV.a.24 (EscB)," Studi musicali 19 (1990): 259-303.

34 On the dating of the Cordiforme Chansonnier, see Chansonnier de Jean de Montchenu (Bibliothèque nationale, Rothschild 2973 [I.5.13]), Geneviève Thibault, ed., with commentary by David Fallows (Paris: Publications de la Société Française de Musicologie, 1991), lviii. 


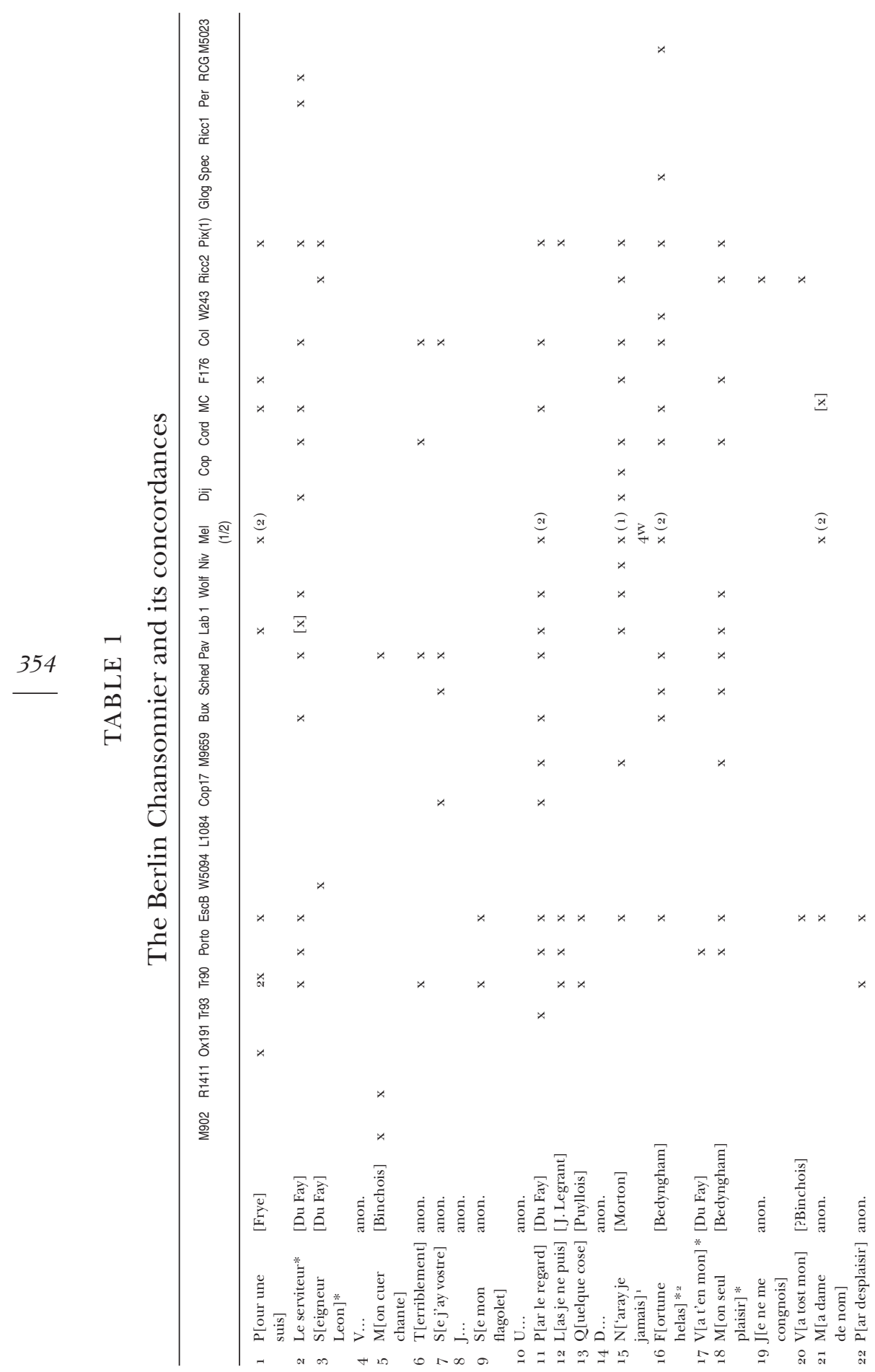




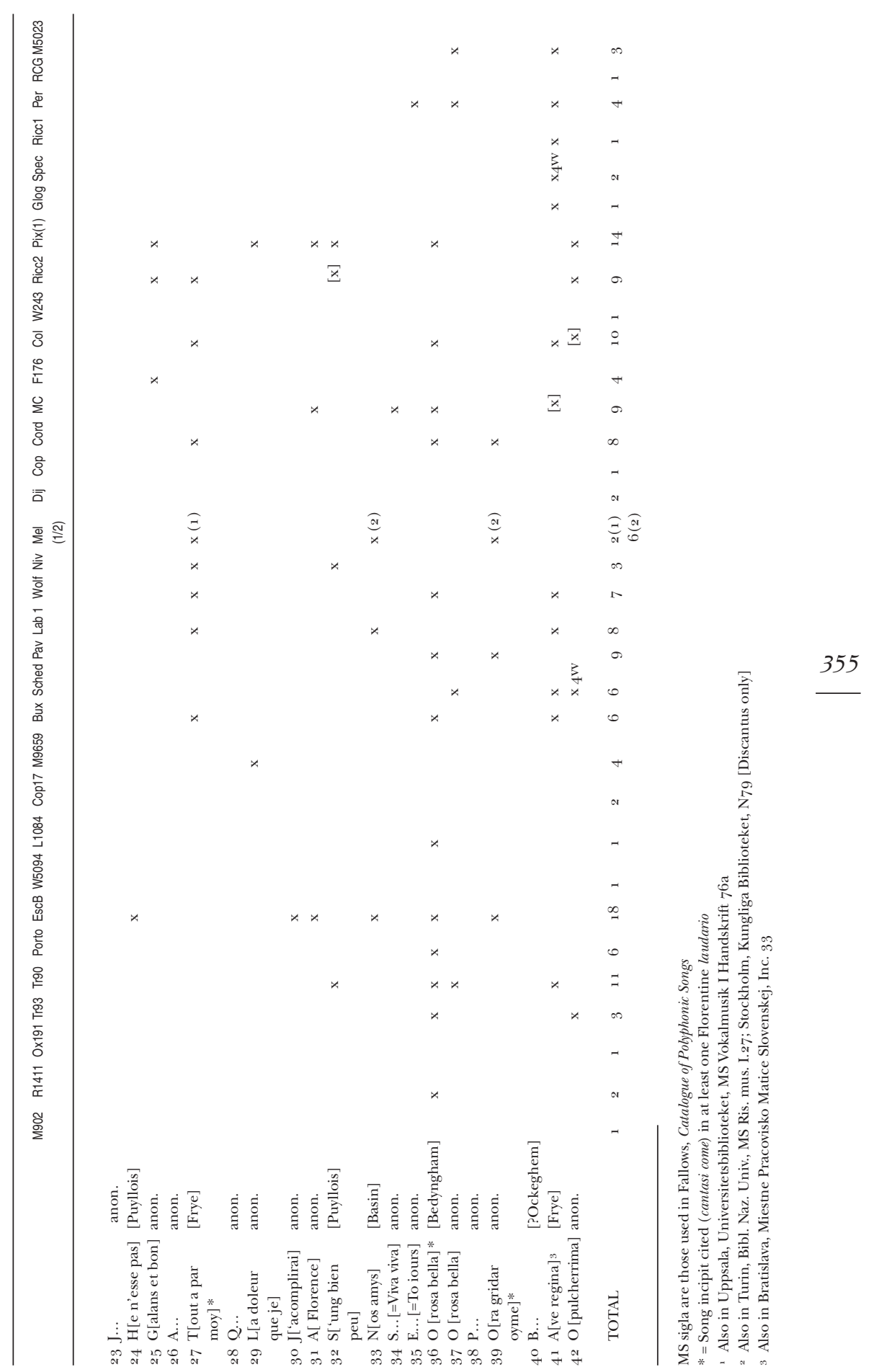


THE JOURNAL OF MUSICOLOGY

in Florence to any significant degree only in the early 1480 , not a decade earlier.

A comparison of the Berlin manuscript with the Mellon Chansonnier provides a case in point. Mellon is a collection of 57 works copied in Naples, by all indications between 1473 and $1475 / 76.35$ The theorist and composer Johannes Tinctoris was employed at the Neapolitan court from late 1472, and two of his works for Beatrice of Aragon appear in the manuscript. He likely had a hand in its compilation. Certainly the music in it reflects his preferences, with many works by composers cited in his treatises, in particular Busnoys (here represented by 15 songs), but also Ockeghem, Caron, and Regis. This emphasis on Busnoys and his contemporaries is true at least for the first section of the manuscript. Leeman Perkins was the first to observe that the scribe of the Mellon Chansonnier divided the collection into two sections, which he separated by a pair of ruled but otherwise empty openings. The two sections are repertorially distinct: Mellon 1, consisting of 44 works, is where the more recent music is found, including all 15 of the songs by Busnoys; Mellon 2, by contrast, has a different and clearly earlier repertory, one much the same as that found in the Berlin manuscript. Indeed, six of the 12 songs in Mellon 2 are found also in Berlin, a strikingly high rate of concordance. $3^{6}$ Just as significant, though, is the low rate of concordance between Berlin and the more modern repertory of Mellon 1: Here there are just two songs in common, both of them widely distributed works by the English composers Morton and Frye.

We will recall that the Berlin Chansonnier contains no known works by Busnoys or Caron.37 The Mellon Chansonnier, on the other hand, is the earliest substantial collection of Busnoys's songs copied in Italy, and the strong presence of his music there is part of what has prompted the belief that his songs were well known elsewhere in Italy beginning in the 1470 os. But we now know that Berlin and Mellon were not copied approximately a decade apart, but rather date from the same years. Evidently, then, the newer chansons by Busnoys and others that were available in Naples in the early $147 \mathrm{os}$, very possibly owing to

35 Leeman L. Perkins and Howard Garey, eds., The Mellon Chansonnier, vol. 2, Commentary (New Haven: Yale Univ. Press, 1979), 3-6.

$3^{6}$ Perkins and Garey, The Mellon Chansonnier, vol. 2, 3-5.

37 Jeffrey Dean has recently argued that one of the unica in Berlin (on fols. $45^{\mathrm{v}}-47$ ) is an otherwise unknown work by Ockeghem. On stylistic grounds this attribution seems to me entirely plausible. But since Ockeghem was already composing songs by ca. $145^{\circ}$, this work, if it is his, could equally belong to the $145^{\mathrm{Os}}$ - that is, to the same earlier repertory as so much of the rest of the collection. Jeffrey Dean, "Okeghem's Valediction?: The Meaning of Intemerata Dei mater," in Philippe Vendrix, ed., Johannes Ockeghem: Actes du XLe colloque international d'études humanistes (Paris: Klincksieck, 1998), 552-54, with a transcription of the song at $568-70$. None of the other unica stand out as likely works by Busnoys, Caron, or their known contemporaries. 
the recent arrival of Tinctoris, had not yet reached Florence when the Berlin Chansonnier was copied. $3^{8}$

If Busnoys's songs were thin on the ground in Florence throughout the 1470 , this would help explain the otherwise surprisingly small number of works by him in some Florentine chansonniers dated to ca. 1480. Two of these manuscripts, Florence Bibl. Naz. 176 and the "Second" Riccardiana Chansonnier, are chronologically the next surviving Florentine sources after the Berlin volume. 39 Whereas in Mellon 1 just over a third of the pieces are by Busnoys, in Florence 176 we find just five pieces by him among its 86 works. Similarly, of the 80 pieces originally copied in the Riccardiana Chansonnier, just one is by Busnoys. At least some of the more recent French repertory must have begun circulating in Florence in the late 1470s, notably the music of Caron, seven of whose songs are in the Riccardiana manuscript. But on the whole one gets a sense of repertorial continuity in Florence in the 1470s: For example, nine of the songs in Berlin, nearly a quarter of the collection, appear also in the "Second" Riccardiana.

We lack solid evidence for the precise copying dates of Florence 176 and the "Second" Riccardiana Chansonnier, and it may be that the new terminus post quem of the Berlin manuscript will prompt us to revise their dates. Whatever their actual dates, there is a consensus that both Riccardiana and Florence 176 , based on their contents, are slightly earlier than the last manuscript I will discuss here, the Pixérécourt Chansonnier (Paris, Bibl. nat., fonds fr., MS 15123), the third surviving Florentine songbook scholars have dated to ca. 1480 or slightly thereafter. $4^{\circ}$ An elegantly decorated manuscript, Pixérécourt is a larger collection than the others, with 171 pieces filling 20 gatherings, all of them copied by a single scribe. It may have been finished by around 1484 , as Allan Atlas has suggested, since it contains no music by Heinrich Isaac, who took up residence in Florence that year. $4^{1}$ There is, however, quite a lot of Busnoys in it-at least 22 securely attributed

$3^{8}$ To my knowledge, none of Busnoys's songs figure in the cantasi come tradition of Florentine laude. Indeed, of the more than 1 oo songs by Busnoys, Caron, and Ockeghem, only one (Caron's Accueilly m'a la belle) is noted by Fallows (Catalogue of Polyphonic Songs) as being in collections of laude. By contrast, one finds several songs by Binchois and Du Fay cited in these collections, including three Du Fay songs in the Berlin Chansonnier.

39 Florence, Bibl. Naz. Centrale, MS Magliabechi XIX. 176 and Florence, Bibl. Riccardiana, MS 2356; see Census-Catalogue of Manuscript Sources, I: 229-30, 244-45.

$4^{\circ}$ Brief descriptions of the manuscript and its contents are in Fallows, Catalogue of Polyphonic Songs, 38; and Census-Catalogue of Manuscript Sources, III: 23-24 and IV: 463.

$4^{1}$ Allan Atlas, The Cappella Giulia Chansonnier (Rome, Biblioteca Apostolica Vaticana, C. G. XIII. 27), Part 1-Commentary (Brooklyn: Institute of Mediaeval Music, 1975), 254-55. New documentation of Isaac's musical activities in Florence during the late 1480 os is discussed in Blake Wilson, "Heinrich Isaac among the Florentines," Iournal of Musicology 23 (2006): 97-152. 
THE JOURNAL OF MUSICOLOGY

songs in all. Previously, in the absence of even one Florentine source securely datable to the $147 \mathrm{Os}$, it has been difficult to determine whether the Pixérécourt manuscript represented a genuinely new development, or whether by 1480 much of this music by Busnoys and his contemporaries had already been circulating in Florence for a number of years, and its small representation in Florence 176 and the "Second" Riccardiana Chansonnier was simply owing to the smaller scope of those collections. Now, however, it appears that Pixérécourt really did mark the watershed moment for Busnoys's music in Florence. $4^{2}$

What is more, it would seem we can pinpoint when much of this new music became available in Florence: namely, when the Pixérécourt scribe was about halfway through his work on the manuscript. A previously unnoticed detail in this scribe's work suggests that Pixérécourt, not unlike the Mellon Chansonnier of a decade earlier, consists of two repertorially distinct sections. Recently, during my first direct encounter with the manuscript, I noted that the scribe's way of writing the voice designation "Tenor" changes abruptly at the end of gathering 12 , and that this changed version then appears consistently throughout the remainder of the manuscript, gatherings 13-20. At the time this seemed just a minor scribal quirk, potentially interesting only because of its consistency. It was only later, while examining concordances between Pixérécourt and other manuscripts, that the significance of this small scribal change became apparent. (For the sake of clarity I will refer here to gatherings $1-12$ as Pix1, and gatherings 13-20 as Pix2.)

A clear pattern of concordances emerged (see Table 2). In manuscripts copied earlier than Pixérécourt, the concordances cluster in Pix1, with few or none in Pix2. This holds true even for the "Second" Riccardiana Chansonnier, a manuscript copied in Florence perhaps just a few years earlier: Of the 39 pieces it shares with Pixérécourt, 30 are in Pix1. Conversely, manuscripts copied in the mid to late 1480 os or later have concordances mostly with Pix2. Another Florentine manuscript illustrates the point: Florence, Bibl. naz., Banco Rari 229, a large collection securely dated to ca. 1492 and decorated by the same artists who worked on Pixérécourt, has $4^{1}$ works in common with it.43 Thirty-one of these concordances are in Pix2, constituting nearly half of all the music in this part of Pixérécourt. By contrast, Pix1, which contains 101 works,

$4^{2}$ These new observations concerning the Berlin Chansonnier reinforce comments made by Joshua Rifkin, who has recently come to a similar conclusion about the significance of the Pixérécourt Chansonnier, noting that it represents "an extraordinary-and extraordinarily sudden-influx of [Busnoys's] music into the Florentine repertory." See his "Busnoys and Italy: The Evidence of Two Songs," in Paula Higgins, ed., Antoine Busnoys: Method, Meaning, and Context in Late Medieval Music (Oxford: Clarendon Press, 1999), 554-55.

43 Brown, ed., A Florentine Chansonnier, cf. note 5 above. 
TABLE 2

Selected manuscripts copied between the $145^{\text {os }}$ and 1490 s and the number of their concordances with the two repertorial layers of the Pixérécourt Chansonnier

Pix $I=$ Gatherings 1-12, 101 works total

Pix2= Gatherings 13-20, 70 works total

Northern MSS from 1460 and 70 os

Laborde (Layer 1)

Wolfenbüttel

PixI Pixz

Nivelle

Dijon

$\begin{array}{ll}14 & 1 \\ 14 & 2 \\ 7 & 1 \\ 15 & 5\end{array}$

Italian or Savoyard MSS from 145 os to ca. 1480

Porto

Escorial B (main corpus, through f. 120)

Berlin

Cordiforme

Mellon 1 (later repertory)

Mellon 2 (earlier repertory)

Montecassino

Florence 176

'Second' Riccardiana

\begin{tabular}{ll}
5 & 0 \\
17 & 1 \\
14 & 0 \\
13 & 2 \\
6 & 8 \\
5 & 0 \\
15 & 6 \\
21 & 9 \\
30 & 9 \\
& \\
14 & 17 \\
11 & 13 \\
3 & 5 \\
10 & 31 \\
\hline
\end{tabular}

shares just ten songs with Florence 229. In terms of concordance patterns, the clearest evidence that Pix 1 contains a chronologically earlier repertory than Pix 2 comes from the Berlin Chansonnier and Escorial B. All 14 of the songs common to Berlin and Pixérécourt are in Pix1, as are all but one of the 18 concordances with Escorial B. 44

There is also the matter of Busnoys's songs in Pixérécourt. Here again the distribution of his music in the manuscript seems to confirm the existence of two repertorial layers. Of his 22 securely attributed

44 For further details of the compilation of the Pixérécourt Chansonnier, see Sean Gallagher, "Caron and Florence: A New Ascription and the Copying of the Pixérécourt Chansonnier," in Pieter Bergé and Mark Delaere, eds., Studies on Renaissance Music in Honour of Ignace Bossuyt (Leuven: Leuven Univ. Press, forthcoming). 
THE JOURNAL OF MUSICOLOGY

songs in Pixérécourt, 18 are in Pix2, with only four in Pix 1-a quantity comparable to the small amount of Busnoys's music found in both Florence 176 and the "Second" Riccardiana Chansonnier. The overall uniformity of the Pixérécourt scribe's work argues against there having been any substantial time lag between the copying of Pix1 and Pix2. Rather, what appears to have happened was that he began by copying chansons that were already available in Florence, a repertory that had evidently changed little during the preceding decade; and then, around the time he was completing gathering 12 , he gained access to a large number of more recent songs by Busnoys and his contemporaries.

A likely conduit for such a large number of songs by Busnoys would have been the arrival in Florence of a singer who had known the composer in the North. The singer Guillaume Steynsel is a promising candidate. Steynsel, who had worked alongside Busnoys as a member of the Habsburg-Burgundian chapel of Maximilian I until his departure in late 1481 , also served for a year as one of the singers of San Giovanni in Florence beginning in August 1484, and then again during the years $1489-92.45$

All of this in turn suggests that the Berlin Chansonnier's unusual repertorial profile may actually be unusual only when viewed in the broader context of northern song in Italy more generally. Within the more circumscribed context of Florence it would now seem that the Berlin manuscript, even with its new terminus post quem and its predominance of older works, was nevertheless a representative collection of the polyphonic songs that were circulating in the city during the early to mid 1470 os.

This conclusion naturally raises other questions: Why did it take longer for this newer music to reach Florence? And was this delay simply a matter of happenstance, or does it perhaps reflect the preferences of Florentine collectors? There is evidence that Florentine tastes in northern songs during this period, at least in Medici circles, tended to be conservative, even old-fashioned. James Haar has recently discovered a remarkable exchange of letters among a group of friends in the circle around Giovanni di Cosimo de' Medici (1421-63).46 These reveal, among many other things, that the Florentine elite were well aware of general stylistic features of chansons, and that in the mid

45 On Steynsel in Florence, see Frank D'Accone, "The Singers of San Giovanni in Florence during the Fifteenth Century," Journal of the American Musicological Society 14 $(1967): 323 n 45$ and 335f; Paula Marie Higgins, "Antoine Busnois and Musical Culture in Late Fifteenth-Century France and Burgundy" (Ph.D. diss., Princeton Univ., 1987), 103, 111. My thanks to Joshua Rifkin for drawing my attention to the possible significance of Steynsel in this context.

$4^{6}$ James Haar, "The Vatican Manuscript Urb. Lat. 141 1," 79-87. 
1440 os the model exponent of that style for them was still Binchois. Nor do Medici tastes seem to have changed much by 1460 , when Bianca de' Medici and other young women performed songs for Pope Pius II and his entourage. 47 An eyewitness account of the event identifies three of the works they performed, two of which-Dueil angoisseux and Mon cuer chante joyeusement-are songs by Binchois. It would seem the latter work continued to be a favorite in Florence even into the 1470 , since it is among the songs in the Berlin Chansonnier. The overall impression is that of a small group of connoisseurs who knew what they liked-and liked what they already knew, an attitude that reveals little concern with being au courant with respect to more recent chansons composed in the North. $4^{8}$

The Medici connection may be relevant here. In trying to determine where the music in the Berlin manuscript might have come from we should turn back to the Niccolini and Castellani families. The Niccolini were closely involved with the Medici, none more so than Margherita's father-in-law, Otto Niccolini (1410-70), the most prominent member of the family and a major political figure in $15^{\text {th-century }}$ Florence. He had studied law at Padua, was a close associate of both Cosimo de' Medici and his sons, served as Gonfaloniere of Florence, and headed numerous diplomatic embassies to Naples, Rome, and elsewhere.49 In the late 1970 Perkins noted that Otto had represented Florence at a diplomatic meeting at the Aragonese court in Naples in 1469 , a date that at the time seemed too late to be of any relevance to the Berlin Chansonnier. $5^{\circ}$ With the revised dating to the early 1470 ,

47 These performances are described in a letter of Teodoro da Montefeltro; for the letter and a discussion of the 1460 performance, see William F. Prizer, "Games of Venus: Secular Vocal Music in the Late Quattrocento and Early Cinquecento," Iournal of Musicology 9 (1991): 3-6, 53-54.

$4^{8}$ Letters written in the late 148 os by Ambrogio Angeni, a young Florentine of modest background and means, do however reveal an avid interest in new music. But there the focus is not on French songs, but rather on settings of Italian texts by a composer (Isaac) who was living in Florence at the time; see the discussion of these letters in Wilson, "Heinrich Isaac Among the Florentines." While Angeni's letters provide valuable information on musical activities in Florence during the last years of Lorenzo de' Medici's life, they do not affect the picture sketched here of patrician tastes in French songs some 20 years earlier. In this context it is worth noting that Robert Nosow, using a different kind of evidence from that explored here-namely, the small number of French songs cited in Florentine laudar- - has reached similiar conclusions about the "social distribution" of French songs, most of which "remained within a circle of connoisseurs who either owned music manuscripts or could afford to hear the songs performed in their private palazzi and villas"; see his "Binchois's Songs in the Feo Belcari Manuscript," in Andrew Kirkman and Dennis Slavin, eds., Binchois Studies (Oxford: Oxford Univ. Press, $2000), 238$.

49 On Otto's career, see Niccolini di Camugliano, The Chronicles of a Florentine Family, $179-326$.

5० Perkins and Garey, The Mellon Chansonnier, vol. 2, 6. 
THE JOURNAL OF MUSICOLOGY

however, the high rate of concordance between Berlin and the Neapolitan Mellon Chansonnier takes on potentially greater significance, as does the presence in Berlin of a song honoring Ferrante I of Aragon that survives elsewhere only in a Neapolitan source of the $147 \mathrm{Os}^{5^{1}} \mathrm{In}$ other words, there seems a real possibility that some (perhaps much) of the music in the Berlin Chansonnier was brought from Naples around 1470. Perhaps Otto Niccolini was the conduit, sending music back to Florence, either for his own purposes, or for the Medici. Otto died in Rome in September 1470 , and so did not live to see his son Bernardino's wedding..$^{2}$ Thus while he might conceivably have had a hand in transmitting some of this music to Florence, he would not have been involved in the actual commissioning of the Berlin Chansonnier. At all events, his four-month visit to Naples in 1469 and his ties to the Medici warrant further investigation.

Finally, there is Margherita Castellani herself, about whom we still know far too little to say anything with confidence about her tastes in music. But there is ample evidence that a young woman of her social class would have been sufficiently well versed in music to be able to sing or play chansons.53 There are even a few tantalizing details to suggest Margherita grew up in a house in which both music and dance had a place. From her father's libro di ricordi we learn that in 1459 he owned two lutes (one large, one small), and that these were apparently used by someone in the family, since he records paying to have them maintained and provided with new strings. 54 In the same source we find that the following year, 1460 , a wind player, identified only as "Bernardo di Sancti piffero," began giving dancing lessons to Margherita and her sister, then aged six and ten.55 Whether as a young woman Margherita cultivated a taste for polyphonic chansons can thus far only be inferred from the existence of her chansonnier. Whatever her own interest in her songbook, for us it remains an undeniably important document of secular music in Quattrocento Italy. While the new evidence presented here concerning her marriage deprives us of what was our only Florentine music manuscript of the 1460 , with its revised dating the Berlin Chansonnier proves to be even more valuable than we had realized for our understanding of northern song in Florence.

Harvard University

$5^{1}$ Viva viva rey Ferrando (no. 34, fols. 37v-39r) survives also in Montecassino, Biblioteca dell'Abbazia, MS 871 (pp. 393-94); but see n22 above concerning the different versions of this song in the two manuscripts.

$5^{2}$ Niccolini di Camugliano, The Chronicles of a Florentine Family, $3^{0} 5^{-6 .}$

53 See Bryce, "Performing for Strangers," 1089-91.

54 Ciappelli, Ricordanze, vol. 2, 65.

55 Ibid., vol. 2, 105. 


\begin{abstract}
Appendix
Excerpts from a letter of Marco Parenti (dated 11 August 1469) to Filippo Strozzi concerning the matrimonial prospects of Filippo's younger brother Lorenzo
\end{abstract}

I see that following his return from the Baths, Lorenzo is interested in taking a wife, and I know that he is more interested than he lets on to me.... I feel much compassion for him, because for many reasons his is a terrible case, worse than any other one now. In the past, he could have struck the best marriage alliances in the land and for various reasons he has chosen not to, for good or ill that might have been. Now he is ready, and there are no comparable matches.... He is very attracted to one of the daughters of Francesco del Benino and to one of the Del Vigna family. They do not belong to families with the same standing as yours; what is more they are not pretty. ... It is necessary that she be of such distinguished lineage that whoever wants to demean her with words will be unable to do so. He does not want her to be rustic, but I find so many problems with those who are available that I do not know to whom to turn, if not to have everything then at least some extraordinary quality: either family, or political standing, or wealth, or exceptional beauty. If I turn my attention to one and there is something lacking in her, that spoils her for me, as is the case with the daughter of Bartolomeo Gianfigliazzi. Here there is beauty and nobility, but her father's circumstances are not very satisfactory. It is the same with a daughter of Federigo Sassetti. ... Here there is less beauty, [but] greater wealth; she goes for 1,600 florins. ... The Vettori girl, as I heard from Tommaso Ginori, passes herself off as very young, and it is questionable whether she will succeed or not. It will be difficult to have even half of her dowry within two years... There is the daughter of Luca Capponi. He [Lorenzo] should consider this one. Luca is absent, since he is Captain of Arezzo, but he will soon return. I do not know what she is like, but if she is pretty and has a large dowry, Lorenzo's possessions are known to him.... There is the second daughter of Francesco Castellani. His first daughter who married is not pleasing in any way, and they say the second is worse [E'.cci la seconda di messer Francesco Castellani, la prima ch'è maritata non piace a verun modo, e la seconda dicono che è peggio]. These are the best I have in mind. You see where we are, so think about it a little yourself because I am at a loss, and tell us your opinion.

(Translation is that published in Anthony Molho, Marriage Alliance in Late Medieval Florence [Cambridge: Harvard Univ. Press, 1994], 230-32, where the Italian text is also provided.)

\begin{abstract}

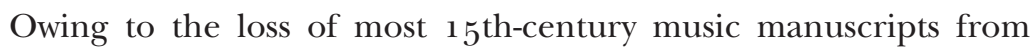
France and Burgundy, chansonniers of Italian origin are of special significance for our knowledge of the French song repertory and its
\end{abstract}


THE JOURNAL OF MUSICOLOGY

dissemination during the second half of the century. Florence appears to have been a particularly important center of collecting, judging from a group of nine chansonniers copied there between the 1440s and the early 1490s. In recent decades the Berlin Chansonnier (Berlin, Staatliche Museen der Stiftung Preussischer Kulturbesitz, Kupferstichkabinett, MS 78.C.28) has held a special place among these Florentine sources, partly because it is the only one from before the 1490 for which there is external evidence that seemed to provide a precise dating, and partly because that evidence indicated that it was our only surviving Florentine music manuscript from the 1460 . More than 30 years ago Peter Reidemeister identified the two Florentine families whose impaled arms decorate the first chanson in the collection. These arms led him to propose that the manuscript was made in connection with a wedding involving these two families, which he claimed took place in 1465 or 1466 , a dating that has been accepted as a terminus ad quem in subsequent scholarship. The manuscript thus appeared to pre-date by 15 or more years the next earliest sources in the Florentine group, and the significant repertorial differences between the Berlin manuscript and those of the early 148 os seemed to reflect this time gap.

Documents in the Archivio di Stato in Florence change this picture considerably. New evidence calls for a series of crucial adjustments to the theories proposed by Reidermeister that together force a reassessment of the dating of the Berlin Chansonnier. This reassessment affects in turn its relation to several other manuscripts, both from Florence and elsewhere in Italy, and provides new insight into the repertory of songs (in particular those of Busnoys) that was circulating in Florence between the 1460 and the early 148 os.

Keywords:

Antoine Busnoys

chanson

chansonnier

Florence

Pixérécourt 